\title{
IMPACT OF IMPLEMENTATION OF TOTAL QUALITY MANAGEMENT: AN ASSESSMENT OF THE SAUDI INDUSTRY
}

\author{
M.S. Abd-Elwahed ${ }^{1 *} \&$ M.A. El-Baz ${ }^{2}$
}

\section{ARTICLE INFO}

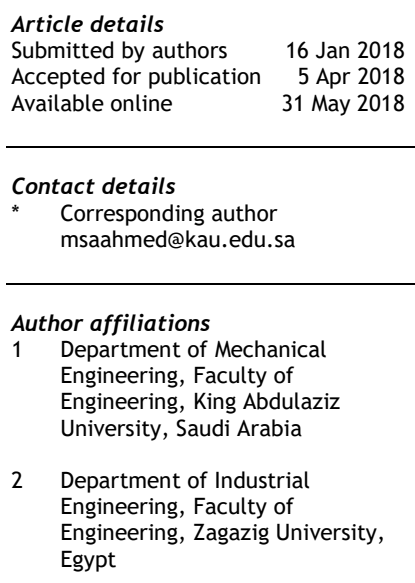

DOI

http://dx.doi.org/10.7166/29-1-1902

\section{ABSTRACT}

The main objective of this research is to measure the level of knowledge, understanding, and implementation of quality management tools in a sample of the industrial sector in Saudi Arabia, and to monitor the different policies to implement the quality strategies and the extent of their integration into the industrial management systems in general. A questionnaire to cover key elements, including knowledge and understanding of the various quality management (QM) approaches and the accompanying tools, is implemented. The impact of using each QM approach on the level of actual growth of the industrial organisations is verified, along with the impact of the executive method of management and its compatibility with the proper implementation of quality tools. The results of the study indicate that different visions of QM strategies and policies are still adopted by industrial companies participating in the survey. In addition, there is a difference in the levels of understanding and implementation of QM tools and techniques.

\section{OPSOMMING}

Die doel van hierdie navorsing is om die vlak van kennis, begrip en implementering van gehaltebestuurgereedskap binne 'n monster van die industriële sektor in Saoedi-Arabië te meet. Verder word die verskillende beleide om gehaltestrategieë te implementeer en die omvang van hul integrasie in industriële bestuurstelsels gemonitor. 'n Vraelys wat sleutelelemente dek, insluitend kennis en begrip van die verskeie gehaltebestuur benaderings en die gepaardgaande gereedskap, is geïmplementeer. Die impak van die gebruik van elke gehaltebestuur benadering op die vlak van werklike groei van die organisasie is geverifieer saam met die impak van die uitvoerende bestuurstyl en die verenigbaarheid daarvan met die behoorlike implementering van gehaltebestuurgereedskap. Die resultate van die studie dui daarop dat verskillende visies van gehaltebestuurstrategieë en beleide nog in die proses is om aangeneem te word deur die maatskappye wat in die peiling deelgeneem het. Verder is daar 'n verskil in die vlakke van begrip en implementering van gehaltebestuurgereedskap en tegnieke.

\section{INTRODUCTION}

Increasing global markets and competition lead companies to work for continuous improvement. Using quality management (QM) practices correctly, industrial companies can assure their success to achieve competitiveness [1]. As improvement strategies to meet customer satisfaction and business excellence, QM initiatives have been used in conjunction with sustainable development initiatives [2], [3]. Therefore, most companies take advantage of total quality management (TQM) practices such as statistical process control and their modern approaches such as Six Sigma, Lean, and agile thinking to produce a better performance [4], [5]. For such approaches, much research has investigated the readiness of people and organisations to implement and take advantage of these 
QM approaches in different countries [6]-[9]. Although QM and its modern practices are increasingly adopted by large numbers of industrial companies worldwide [3], in many regions - such as the Middle East - they are only slowly being adopted [10], [11]. As an indicator to measure the extent of QM practices being used in the Middle East, Figure 1 shows the level and trend of QM in Saudi Arabia along with some peer countries, based on the number of ISO 9001 certificates obtained up to 2015. It also clearly shows the increase of about 125 per cent in the number of ISO certificates issued during the five years, 2011 to 2015.

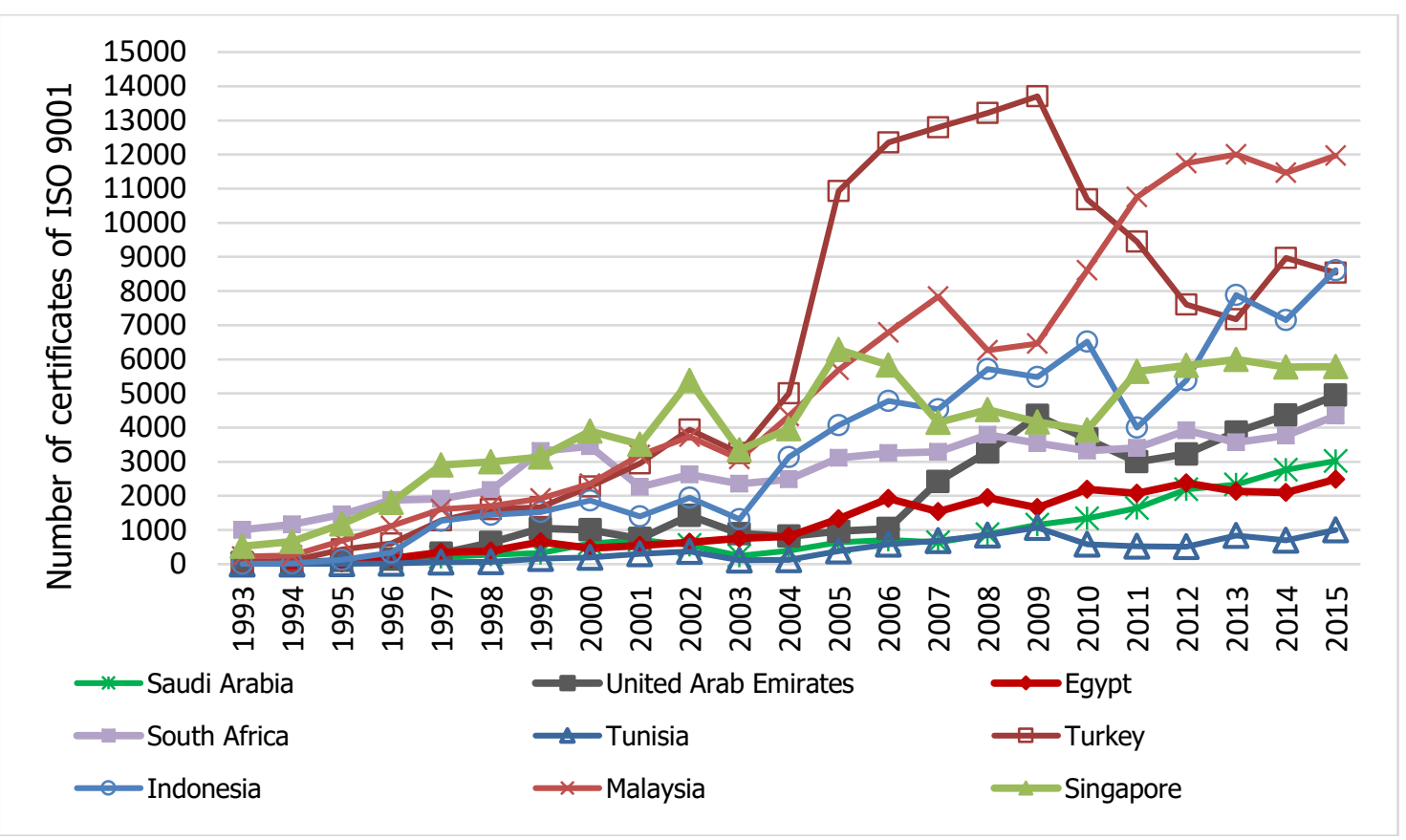

Figure 1: ISO 9001 certificates in some Middle Eastern and African countries (see online
version for colour)

Several authors [6], [12]-[14] have conducted reviews and presented various lists of QM success factors that have been collected from quality experts [15]-[19]. Recently, the success factors of QM have contributed to a new emphasis on training, understanding, and use of QM tools and techniques alongside the previous emphasis on top management commitment or resource allocation [20], [21], [22]. Many academic researchers and quality experts argue that QM tools are one of the most important success factors in many QM initiatives [23]-[25].

QM implementation requires specific tools and techniques for an organisation to achieve success. The quality tools and techniques are in many statistical and heuristic forms, and are applicable in every aspect of business [26], [27]. Uluskan [20] reviewed numerous tools referred to 'Six Sigma' for use in $\mathrm{QM}$, and identified which of them are most frequently used. This study has selected $74 \mathrm{QM}$ tools and techniques from different academic and practical resources [20], [28]-[30].

It is of great importance that quality practitioners are able to identify barriers to the success of QM practices - particularly those that have the greatest effect on performance improvement [31]. A large number of publications have highlighted the barriers found in QM practices in different industry sectors globally [32], [33]. Thus 17 barriers selected through a literature review [10], [34] are investigated through an empirical study to identify the most important ones, particularly those that have not been thoroughly studied in relation to Saudi Arabian industries.

This study aims to determine the extent of quality practitioners' understanding and implementation of QM approaches and their tools in industrial companies, and to identify the QM tools and techniques required in the awareness programmes. It also attempts to identify the significant barriers that hinder the successful use of $Q M$, and proposes recommendations to increase the effectiveness of 
training by focusing on where understanding is inadequate, to overcome the barriers to implementing QM practices and tools.

\section{METHODOLOGY}

This study measures the degree of industrial companies' readiness to implement QM approaches and to use their tools and techniques properly. A survey aimed to report on the views of quality practitioners at various managerial and technical levels about the implementation of quality initiatives and their tools.

\subsection{Questionnaire structure}

The design of the survey has gone through various stages and prior tests, leading to the elimination of some elements of the questionnaire and rebuilding others. The final questionnaire is divided into four major parts:

Part 1 - Respondent's profile: It collects information about each respondent, such as position, professional experience, and industry type.

Part 2 - QM approaches: This part identifies which QM approaches are adopted by the company, and the impact level of each of them. The respondents were asked to rate the QM approaches, using a five-point Likert scale ( $1=$ very low impact to $5=$ very high impact $)$ to indicate the extent to which the QM approach influences company performance.

Part 3 - Quality tools and techniques: This part measures the extent of understanding and implementing the QM tools and techniques (including 74 tools). Each respondent was asked to rate his understanding and use of these tools, using a five-point Likert scale. The understanding of the tools was rated from 1 to 5 (where 1 = Do not know and $5=$ excellent understanding), while the practical use of the tools through the company was rated from 1 to 5 (where $1=$ Not at all and $5=$ extensive use).

Part 4 - Resistance factors to implementing $Q M$ approaches in industrial companies: this was included to identify the essential barriers to implementing the $Q M$ approaches and their tools successfully. Each respondent was asked to rate the statements using a five-point Likert scale to say how much they agreed with the statement (where $1=$ strongly disagree and $5=$ strongly agree).

\subsection{Sample}

The questionnaires were distributed among the industrial companies operating in Saudi Arabia via email and in personal interviews with the respective quality and development officials. In total, 71 out of 231 distributed questionnaires were received, yielding a response rate of about 31 per cent. This number of received questionnaires can be explained by the difficulty of communicating with quality practitioners in the industrial sector. In previous studies of Saudi construction companies specifically, in the Hail region - the response rate was 20.6 per cent [35]. Because of the difficulty in approaching industrial companies, Kerfai et al. [36] collected 40 respondents, using personal interviews, to complete an empirical study of Tunisian manufacturing companies.

\subsection{Scale reliability}

The degree of data reliability is measured using Cronbach's alpha, which is the most widely used measure to assess the internal consistency of the question scales used for data collection [11]. The reliability coefficient is considered acceptable if Cronbach's alpha is at 0.7 or more [24], [37], [38]. The dataset of the respondents was analysed using statistical techniques performed with the Minitab software package and MS Excel. The analyses were debated during a workshop held in the Saudi Quality Council (SQC), comparing the results with the second national survey, which was conducted at the end of 2015. It was attended by more than 25 different QM professionals. The survey targets the professional bodies related to quality management experience in the industrial area. 
In this study, the Cronbach's alpha coefficient is calculated for each element of the survey. The results in Table 1 show that the Cronbach's alpha coefficients range from 0.8460 to 0.9746 , and so the scale used in the survey is reliable for this study.

Table 1: Cronbach's alpha

\begin{tabular}{|l|l|l|}
\hline Survey part & Number of questions & Cronbach's alpha \\
\hline Quality management approaches & 6 & 0.8460 \\
\hline Quality tool understanding & 74 & 0.9746 \\
\hline Quality tools implementation & 74 & 0.9688 \\
\hline Resistance factors to QIM & 17 & 0.8983 \\
\hline
\end{tabular}

\subsection{Population analysis}

The sample studied included companies from different branches of industry (automotive, electrical, plastic, metal-forming, food-processing, and chemical). The number of employees is less than 200 in most companies. All of these companies had a quality management system (QMS).

Analysis of the respondents' profiles shows that all had at least seven years' experience in industry, with 73 per cent of respondents having five years' experience in quality management. Figure 2 depicts the experience profile of the respondents.

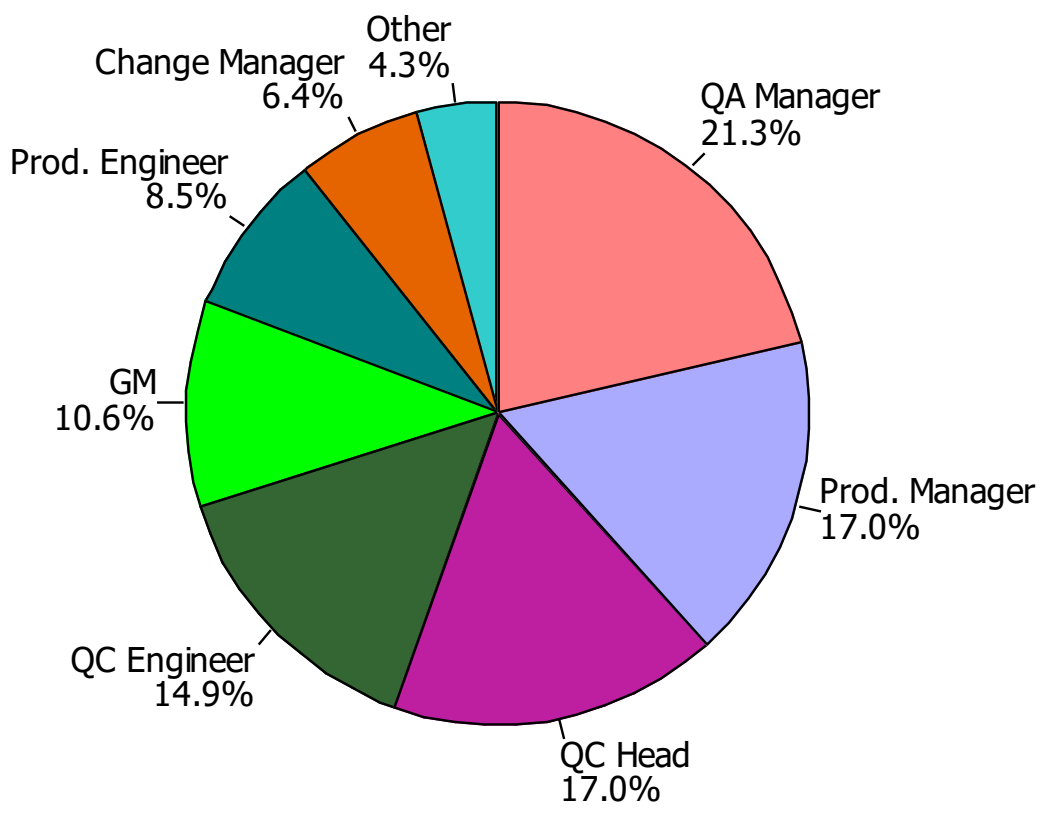

Figure 2: Respondents' profile

\subsection{Implementing QM approaches}

All companies participating in this study have QMS, and most of them have an ISO-9001 certificate. The percentages of the implementation of quality standards and initiatives in the study sample are shown in Figure 3. Both the Lean approach and Six Sigma are used in about 40 per cent of the companies. The large-scale companies, such as Saudi Aramco, use both TQM and its modern improvement methods, such as Lean manufacturing and Six Sigma.

As for Lean production and the Six Sigma approach, 65 per cent of the companies do not use any of them. Looking at the companies that do implement Six Sigma, it was found that they did not have a coherent programme; with attempts, do not exceed some of the projects aiming to test the performance of some Six Sigma tools. 


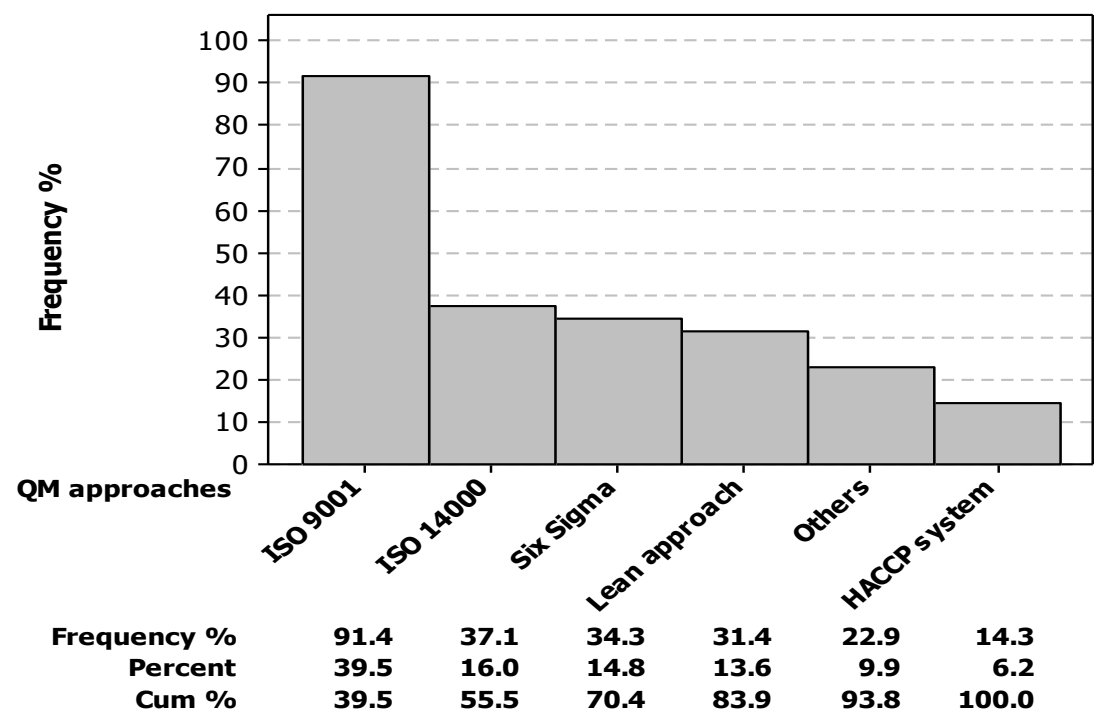

Figure 3: Implementation percentages of QM approaches

About 15 per cent of the companies that participated in the survey follow the Hazard Analysis and Critical Control Point (HACCP) system. This represents all of the companies working in the food industry. With respect to their impact on improving company performance, 80 per cent of the respondents saw it having a high positive impact.

The results of the impact of QM approaches on companies are ranked according to their mean values in Table 2. Many respondents see that the QM approaches used at their company have a positive impact on quality improvement, with mean values ranging from 3.31 to 3.85 . Figure 4 illustrates the respondents' views of the impact level of QM approaches adopted in their respective companies, along with other implemented standards such as OHSAS 18000, ISO 22000, and ISO/IEC 17025.

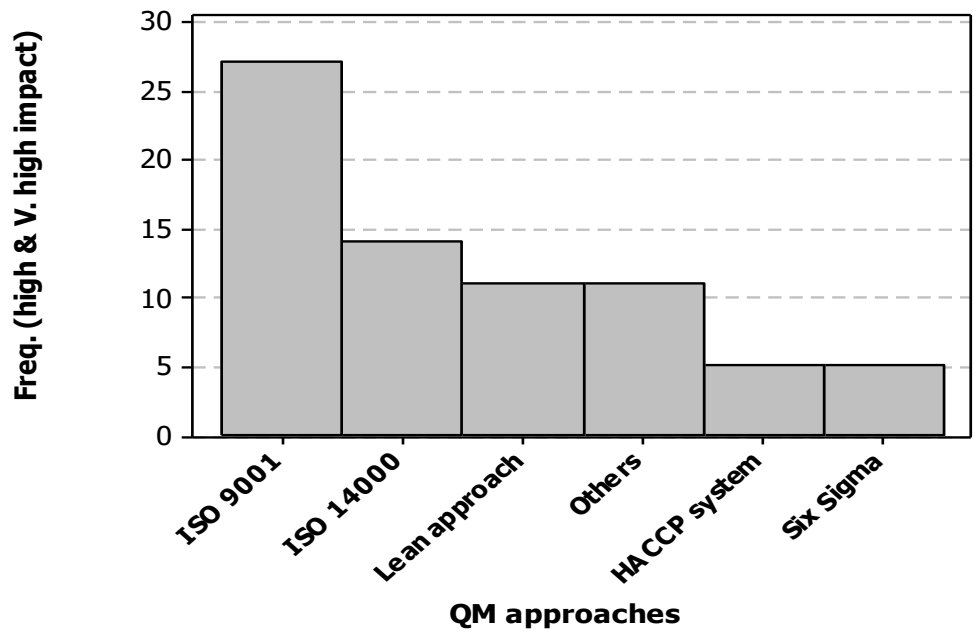

Figure 4: Impact level of QM approaches 
Table 2: QM initiatives and standards: Implementation and impact

\begin{tabular}{|l|c|c|}
\hline QM approaches & Frequency \% & Impact mean value \\
\hline ISO 9001 & 91.4 & 3.85 \\
\hline Six Sigma & 34.3 & 3.31 \\
\hline Lean approach & 31.4 & 3.75 \\
\hline HACCP system & 14.3 & 3.50 \\
\hline ISO 14000 & 37.1 & 3.84 \\
\hline Others & 22.9 & 4.13 \\
\hline
\end{tabular}

\subsection{Understanding of quality tools}

One of the major objectives of the survey is to measure the understanding of QM tools and techniques. The results are shown in Table 3, sorted by the average mean value of the degree of understanding in descending order. It can be seen that the average mean values of the understanding of the tools have a wide spread, ranging from 1.45 to 4.09. It can also be noted that 69 per cent of the tools do not exceed the theoretical understanding level. This result indicates that the majority of the companies participating in this survey have inadequate training programmes.

From Table 3, it can be noted that only four of the 74 tools are placed above the mean response value of 4 , which suggests an inadequate level of experience among 71 per cent of the respondents who have used the quality practices for at least five years. The next 24 tools in the list are placed between the levels of 'theoretical' and 'good' understanding. Finally, 38 out of the 74 tools are placed in the 'low' understanding level, and range from 'poor' to 'moderate', while nine tools are at the level of no understanding at all. This last group of tools (which include scatter diagram, SIPOC, correlations, regression, quality cost model, and gauge R\&R), located at the level of 'poor knowledge', include many tools and techniques that are regarded as fundamental to success in many QM strategies and improvement initiatives. In addition, the 'poorly understood' tools are regarded as basic for people who are in charge of quality process improvement, and are also included in fundamental QM courses such as the Lean Six Sigma green belt.

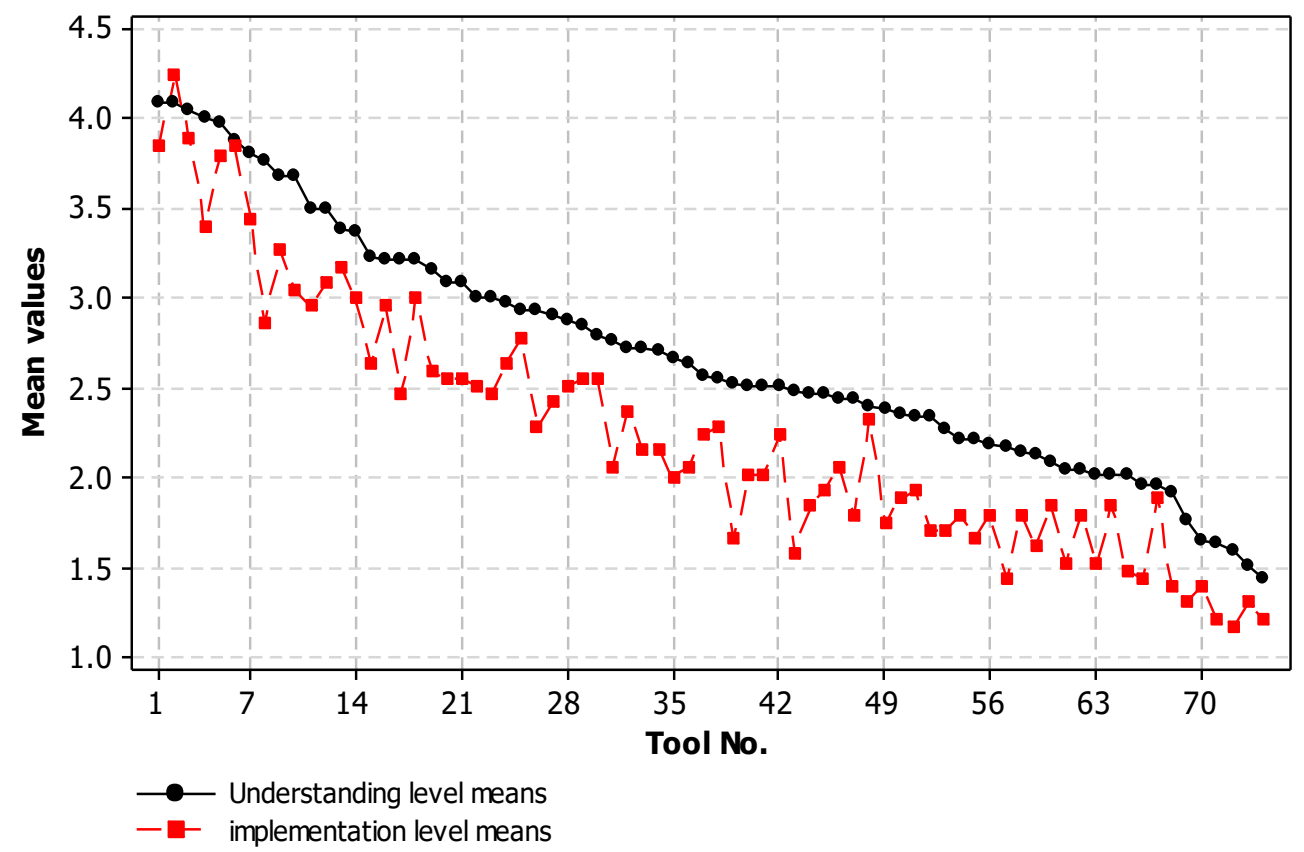

Figure 5: Pattern of understanding and implementation levels

In addition, by reviewing the levels of knowledge and understanding of tools, it is evident that particular tools are better understood when implementing both Six Sigma and Lean manufacturing 
than in other approaches and standards. This is due to need to train people in the use of these tools, which are part of the mandatory toolkit included in the programmes of both approaches.

\subsection{Implementation of quality tools}

Many respondents expressed the view that the tools are implemented either rare or not at all, as shown in Table 3. The curve of the degree of the implementation of the tools represented in Figure 5 reveals that only one tool is identified as used frequently (above the average mean value of 4) that is, key performance indicators (KPIs). In addition, the results indicate that the tools supporting design and innovation, such as quality function deployment, design of experiments, Taguchi's quality loss function, simulation, and TRIZ, were placed in the lowest levels of both understanding and implementation. It is necessary, therefore, to increase training in these tools in these industries, especially as there is a relationship between approaches to improvement and creativity [38], [39].

Two curves represented in Figure 5 show that there is a gap between the levels of understanding and implementation for quality tools such as the 5 whys, cause and effect diagrams, Pareto, and control charts, which have the highest means for understanding in the study sample. The results obviously show that the degrees of implementation and understanding the tools are correlated, with a correlation coefficient of 0.98 . Figure 6 shows the relationship between understanding the tools and implementing them with a line of best fit:

Implementaion level $=-0.4973+1.024 *$ Understanding level
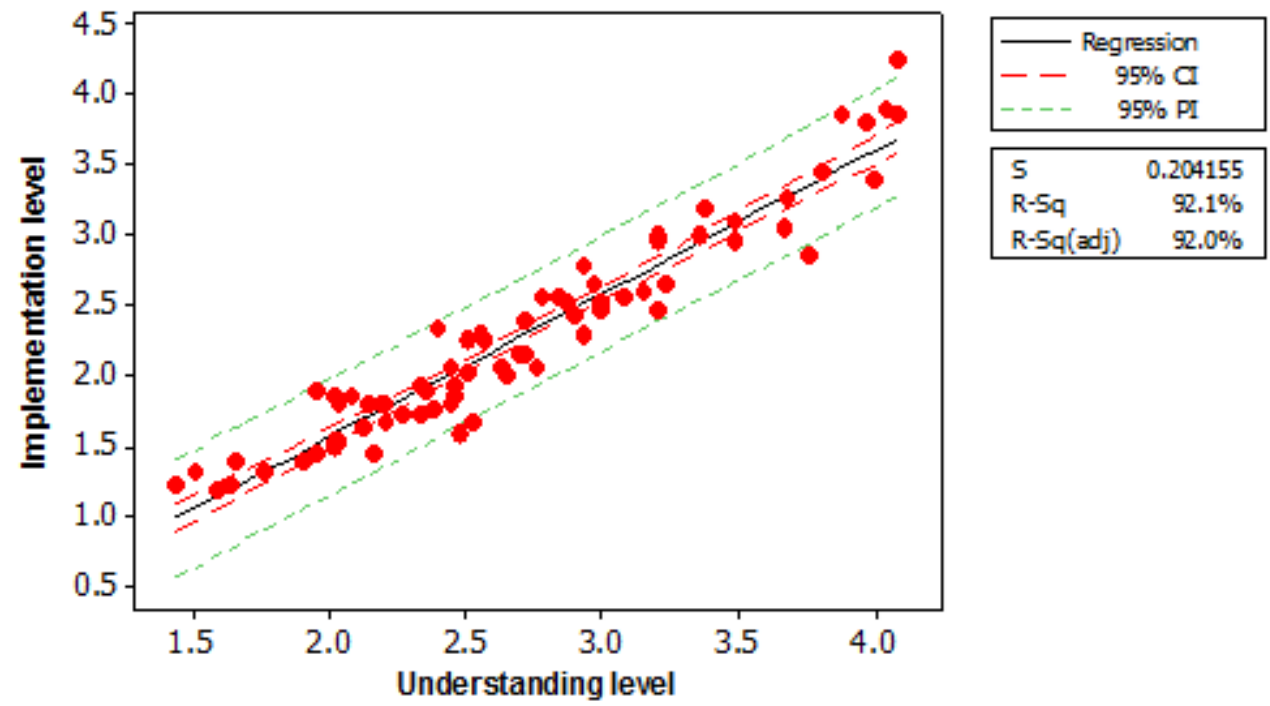

Figure 6: Relationship between understanding and implementation of QM tools

\subsection{Barriers to QM implementation}

This part of the survey aims to identify barriers to the implementation of QM practices. For this purpose, seventeen resistance factors are examined. The results obtained through analysis, shown in Table 4, demonstrate that most of the obstacles assessed in this survey have an effect on QM performance, thus indicating a poor quality culture throughout the region being studied. The first four barriers that the majority of respondents identified are: (1) Lack of training and employee development, (2) lack of leadership support, (3) lack of links between quality, strategy, and operations, and (4) resistance to change. These results are consistent with the poor degree of knowledge of QM tools and techniques, as well as of their implementation. Therefore, in order to overcome these barriers, the leadership should focus on training and awareness programmes to develop employees in accepting the change. More than 70 per cent of the respondents either agree or strongly agree about the barriers mentioned above. Figure 7 shows the interval plot of their agreement with statements about the barriers, ranked in descending order. 
Table 3: Mean values of understanding and implementation of $Q M$ tools

\begin{tabular}{|c|c|c|c|c|c|c|c|}
\hline no & Tool & 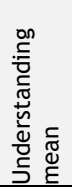 & 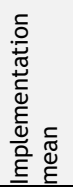 & no & Tool & 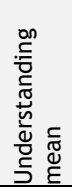 & 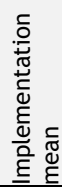 \\
\hline 1 & Basic statistics & 4.09 & 3.84 & 38 & Poke yoke & 2.55 & 2.29 \\
\hline 2 & KPIs (Key Performance Indicators) & 4.09 & 4.24 & 39 & Ease/Impact & 2.53 & 1.67 \\
\hline 3 & Process flow chart & 4.05 & 3.79 & 40 & Correlation & 2.51 & 2.02 \\
\hline 4 & Brainstorming & 4.04 & 3.89 & 41 & Value analysis & 2.51 & 2.02 \\
\hline 5 & Cause and effect diagrams & 4.00 & 3.40 & 42 & Time and motion studies & 2.51 & 2.24 \\
\hline 6 & Preventive maintenance & 3.95 & 3.84 & 43 & Box plots & 2.49 & 1.58 \\
\hline 7 & $5 S$ & 3.81 & 3.44 & 44 & Regression & 2.47 & 1.84 \\
\hline 8 & 5 whys & 3.76 & 2.87 & 45 & Team profiling & 2.47 & 1.93 \\
\hline 9 & Process mapping & 3.68 & 3.27 & 46 & Survey design and analysis & 2.45 & 2.07 \\
\hline 10 & Pareto & 3.67 & 3.04 & 47 & Analysis of variance (ANOVA) & 2.45 & 1.80 \\
\hline 11 & Histogram & 3.49 & 2.96 & 48 & Balanced scorecard & 2.40 & 2.33 \\
\hline 12 & Benchmarking & 3.49 & 3.09 & 49 & Fault tree analysis & 2.38 & 1.76 \\
\hline 13 & Check sheet & 3.38 & 3.18 & 50 & Reliability metrics & 2.36 & 1.89 \\
\hline 14 & Control charts & 3.36 & 3.00 & 51 & СTQ (ritical to quality) trees & 2.34 & 1.93 \\
\hline 15 & Project charter & 3.23 & 2.64 & 52 & $\begin{array}{l}\text { QFD } \\
\text { (Quality function deployment) }\end{array}$ & 2.34 & 1.71 \\
\hline 16 & Process layouts & 3.21 & 2.96 & 53 & DOE (Design of experiments) & 2.28 & 1.71 \\
\hline 17 & What where when ... & 3.21 & 2.47 & 54 & Multi-vari analysis & 2.21 & 1.80 \\
\hline 18 & Standard operations & 3.21 & 3.00 & 55 & $\begin{array}{l}\text { SMED } \\
\text { (Single minute exchange of dies) }\end{array}$ & 2.21 & 1.67 \\
\hline 19 & Sampling plans & 3.15 & 2.60 & 56 & Quality loss function & 2.19 & 1.80 \\
\hline 20 & Gantt chart & 3.09 & 2.56 & 57 & Kano analysis & 2.17 & 1.44 \\
\hline 21 & Process capability & 3.09 & 2.56 & 58 & Quality cost model & 2.15 & 1.80 \\
\hline 22 & Input/output analysis & 3.00 & 2.51 & 59 & $\begin{array}{lll}\begin{array}{l}\text { Activity } \\
\text { (CPA; PERT) }\end{array} & \text { network } & \text { diagram } \\
\end{array}$ & 2.13 & 1.62 \\
\hline 23 & Quality circles & 3.00 & 2.47 & 60 & Stratification analysis & 2.09 & 1.84 \\
\hline 24 & $\begin{array}{l}\text { TPM } \\
\text { (Total productive maintenance) }\end{array}$ & 2.98 & 2.64 & 61 & $\begin{array}{l}\text { Measles charts } \\
\text { (Defect location check sheet) }\end{array}$ & 2.04 & 1.53 \\
\hline 25 & $\begin{array}{l}\text { OEE } \\
\text { (Overall equipment effectiveness) }\end{array}$ & 2.95 & 2.42 & 62 & Hoshin planning & 2.04 & 1.80 \\
\hline 26 & Visual management & 2.94 & 2.78 & 63 & Contingency tables & 2.02 & 1.53 \\
\hline 27 & $\begin{array}{l}\text { FMEA } \\
\text { (Failure mode \& effect analysis) }\end{array}$ & 2.94 & 2.29 & 64 & Personality profiling & 2.02 & 1.84 \\
\hline 28 & Statistical process control & 2.87 & 2.51 & 65 & Affinity diagrams & 2.02 & 1.49 \\
\hline 29 & Recognition and reward system & 2.85 & 2.56 & 66 & Force field analysis & 1.96 & 1.44 \\
\hline 30 & Best practice sharing & 2.79 & 2.56 & 67 & Gauge R\&R & 1.96 & 1.89 \\
\hline 31 & Scatter plots & 2.77 & 2.07 & 68 & Simulation discrete & 1.91 & 1.40 \\
\hline 32 & Process measurement dashboards & 2.72 & 2.38 & 69 & Moments of truth (MoTs) & 1.77 & 1.31 \\
\hline 33 & Kanban & 2.72 & 2.16 & 70 & $\begin{array}{l}\text { Weibull analysis } \\
\text { (life data analysis) }\end{array}$ & 1.66 & 1.40 \\
\hline 34 & Value stream mapping & 2.70 & 2.16 & 71 & Montecarlo simulation & 1.64 & 1.22 \\
\hline 35 & SIPOC & 2.66 & 2.00 & 72 & $\begin{array}{l}\text { IDEF modelling (Integrated } \\
\text { definition modelling techniques) }\end{array}$ & 1.60 & 1.18 \\
\hline 36 & Stakeholder analysis & 2.64 & 2.07 & 73 & Service blue printing & 1.51 & 1.31 \\
\hline 37 & Pilot testing & 2.57 & 2.24 & 74 & TRIZ & 1.45 & 1.22 \\
\hline
\end{tabular}




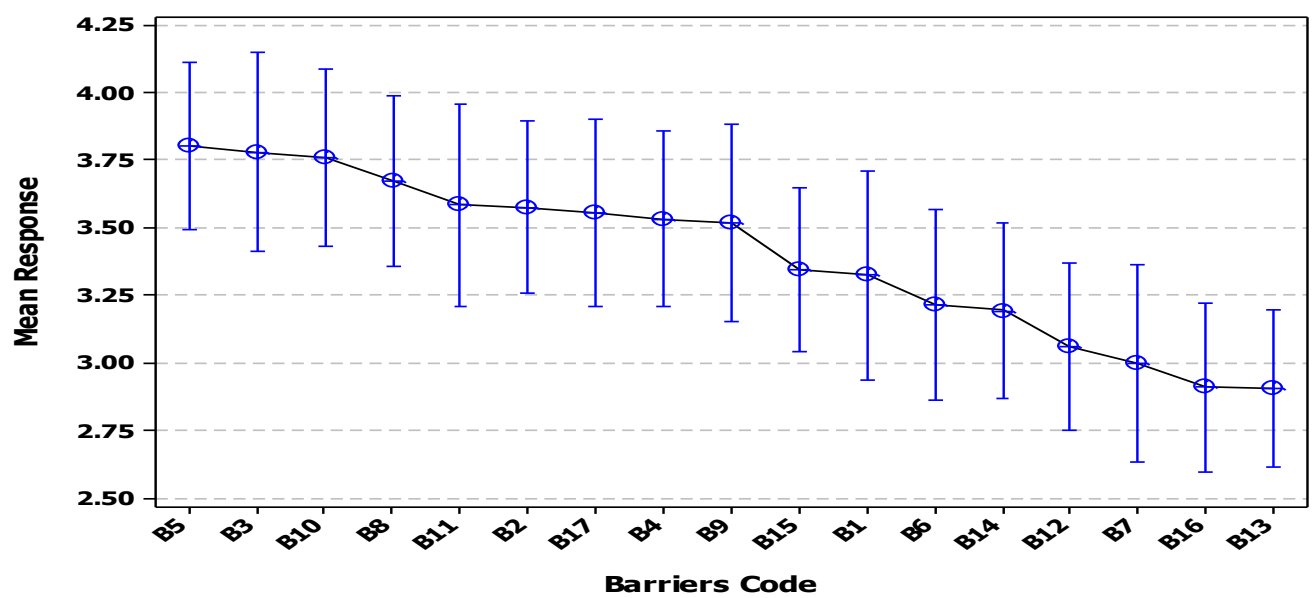

Figure 7: Boxplot (interval plot) of agreement with statements about barriers

Table 4: Barriers to QM implementation

\begin{tabular}{|l|l|l|}
\hline Code & QM implementation barriers & Mean \\
\hline B5 & Lack of training and employee development & 3.86 \\
\hline B3 & Lack of leadership support & 3.78 \\
\hline B10 & Lack of links between quality, strategy, and operations & 3.76 \\
\hline B8 & Resistance to change & 3.67 \\
\hline B11 & Lack of implementation planning & 3.59 \\
\hline B2 & Lack of communication & 3.58 \\
\hline B17 & Cost higher than budgeted & 3.56 \\
\hline B4 & Complexity of implementation & 3.53 \\
\hline B9 & Lack of shared responsibility among sectors & 3.52 \\
\hline B15 & Do not disseminate positive result & 3.35 \\
\hline B1 & Bureaucracy during implementation & 3.33 \\
\hline B6 & Lack of time to implement more complex practices & 3.22 \\
\hline B14 & Lack of credibility of those who are implementing & 3.20 \\
\hline B12 & Existence of different subcultures & 3.07 \\
\hline B7 & Lack of technical knowledge & 3.00 \\
\hline B16 & Negative history of other implementations & 2.91 \\
\hline B13 & Using preset models, bumping into macro-cultural differences & 2.91 \\
\hline
\end{tabular}

\section{DISCUSSION}

Despite the low level of the implementation of QM approaches in the participating companies, the respondents emphasised that the approaches used by their companies have a positive impact on operational performance. On the other hand, all official bodies responsible for quality seek to spread the culture of quality. Consequently, during the next few years, it is expected to increase the levels of understanding and implementation of quality tools in companies in these industries.

Results from the companies that were surveyed revealed that 69 per cent of the QM tools did not exceed the respondents' theoretical understanding level, and more than 12 per cent of the tools were not known at all. In addition, the average level of understanding of the tools was not commensurate with the average level of the respondents' experience, which emphasises the need to invest in training and to seek to develop effective training programmes. It was also found that the levels of understanding and implementing quality tools were strongly correlated.

From investigating barriers to QM implementation, many reasons were found to explain the low level of the actual implementation. The key ones were a lack of training; a lack of links between quality, strategy, and operations; a lack of support from the leadership; and resistance to change. 
A major obstacle to the implementation of QM strategies and tools in the organisations that was identified was a lack of training and employee development. This study also found that many experienced respondents have no inclination to teach people working under their leadership to transfer their experience. There are no rules in place to ensure the exchange of knowledge between people in the same company. Thus industrial companies must use their experts who are equivalent to the black belt or higher to activate employees' self-learning, and develop a mechanism for the transfer and circulation of knowledge between people. Education and training institutions such as universities and training centres should review their curricula, and ensure that their graduates have problem-solving skills and learn the effective and proper use of the quality tools, and their convictions about the necessity of use of QM tools are changed.

Many companies in the world, especially in the Middle East, adopt two or more quality management approaches at the same time. From the literature and from this empirical study, most of these companies do have not a conceptual model to maximise the benefits of integrated management systems [3], [40]. In addition, such integrated systems have to link QM practices to organisational strategies and executive operations to deploy a quality culture in many directions.

\section{CONCLUSIONS}

This study has focused on measuring the extent of the current use of quality tools and techniques (with Saudi industrial companies as a test case), based on a quantitative and qualitative analysis of survey data. It has also attempted to identify the significant barriers to QM implementation, as well as the key training needs in QM for the industrial sectors.

In conclusion, in order to take advantage of $Q M$ efforts, $Q M$ practices should be linked to organisational strategy and tactical operations to encourage top management to support quality culture, beginning with a quality vision and quality values. In addition to the concept of QM and its full integration into the management style of industrial systems, companies must not limit their choices only to some QM methods and their tools; they need to all of them, along with guidelines to implement them. Finally, the different understandings of the concept of selecting some QM tools and policies in industrial management systems should be unified into an integrated system. This system should include every aspect of work, from the planning and production centres to detailed performance reports for each activity and at each level in the industrial organisation.

\section{ACKNOWLEDGEMENT}

This work was funded by the Deanship of Scientific Research (DSR), King Abdulaziz University, Jeddah, under grant number 135-718-D1435. The authors acknowledge with thanks the DSR's technical and financial support.

\section{REFERENCES}

[1] Ahmed, S. and Hassan, M. 2003. Survey and case investigations on application of quality management tools and techniques in SMls. Int. J. Qual. Reliab. Manag., 20(7), 795-826.

[2] Antony, J., Vikas, G.E.V. and Ghadge, K.A. 2016. A multiple case study analysis of Six Sigma practices in Indian manufacturing companies. Int. J. Qual. Reliab. Manag., 33(8), 1138-1149.

[3] Siva, V., Gremyr, I., Bergquist, B., Garvare, R., Zobel T. and Isaksson, R. 2016. The support of quality management to sustainable development: A literature review. J. Clean. Prod., 138, 148-157.

[4] Hietschold, N., Reinhardt, R. and Gurtner, S. 2014. Measuring critical success factors of TQM implementation successfully - A systematic literature review. Int. J. Prod. Res., 52(21), 6254-6272.

[5] Raja Sreedharan, V., Raju, R., Rajkanth, R. and M. Nagaraj, R. 2016. An empirical assessment of Lean Six Sigma awareness in manufacturing industries: Construct development and validation. Total Qual. Manag. Bus. Excell., 29(5-6), 686-703.

[6] Oliveira, G.S., Corrêa, J.E., Balestrassi, P.P., Martins, R.A. and Turrioni, J.B. 2017. Investigation of TQM implementation: Empirical study in Brazilian ISO 9001-registered SMEs. Total Qual. Manag. Bus. Excell., 3363(May), 1-19.

[7] Shokri, A., Waring, T.S. and Nabhani, F. 2016. Investigating the readiness of people in manufacturing SMEs to embark on Lean Six Sigma projects. Int. J. Oper. Prod. Manag., 36(8), 850-878.

[8] Bhuiyan, N. and Baghel, A. 2005. An overview of continuous improvement: From the past to the present. Manag. Decis., 43(5), 761-771. 
[9] Azadeh, A., Zarrin, M., Abdollahi, M., Noury, S. and Farahmand, S. 2015. Leanness assessment and optimization by fuzzy cognitive map and multivariate analysis.. Expert Syst. Appl., 42(15-16), 6050-6064.

[10] Alsmadi, M., Lehaney, B. and Khan, Z. 2012. Implementing Six Sigma in Saudi Arabia: An empirical study on the Fortune 100 firms. Total Qual. Manag. Bus. Excell., 23(March) 2012, 263-276.

[11] Aljabr, A. 2015. Challenges and opportunities of Lean and Six Sigma for Saudi industries, in International Conference on Industrial Engineering and Operation Management, 1-5.

[12] Dayton, N.A. 2001. Total quality management critical success factors, a comparison: The UK versus the USA. Total Qual. Manag., 12(3), 293-298.

[13] Assarlind, M. and Gremyr, I. 2013. Critical factors for quality management initiatives in small- and medium-sized enterprises. Total Qual. Manag. Bus. Excell., 25(3-4), 397-411.

[14] Lande, M., Shrivastava, R.L. and Seth, D. 2016. Critical success factors for Lean Six Sigma in SMEs (small and medium enterprises). TQM J., 28(4), 613-635.

[15] Ishikawa, K. 1976. Guide to quality control. Asian Productivity Organisation- Tokyo.

[16] Feigenbaum, A. 1983. Total quality control. New York: McGraw-Hill.

[17] Neave, H.R. 1987. Deming's 14 points for management: Framework for success. J.R. Stat. Soc. Ser. D., 36(5), 561-570.

[18] Juran, J.J. 1992. Juran on quality by design. New York: Free Press.

[19] Crosby, P.B. 2005. Crosby's 14 steps to improvement. Qual. Prog., (December), 60-64.

[20] Uluskan, M. 2016. A comprehensive insight into the Six Sigma DMAIC toolbox. Int. J. Lean Six Sigma, 7(4).

[21] Brun, A. 2011. Critical success factors of Six Sigma implementations in Italian companies. Int. J. Prod. Econ., 131(1), 158-164.

[22] Aboelmaged, M.G. 2010. Six Sigma quality: A structured review and implications for future research. Int. J. Qual. Reliab. Manag., 27(3), 268-317.

[23] Ribeiro de Jesus, A., Antony, J., Lepikson, H.A. and Peixoto, A.L.A. 2016. Six Sigma critical success factors in Brazilian industry. Int. J. Qual. Reliab. Manag., 33( )6, 702-723.

[24] Kuvvetli, Ü., Firuzan, A.R., Alpaykut, S. and Gerger, A. 2016. Determining Six Sigma success factors in Turkey by using structural equation modeling. J. Appl. Stat., 43(4), 738-753.

[25] Clegg, B., Rees, C. and Titchen, M. 2010. A study into the effectiveness of quality management training: A focus on tools and critical success factors. TQM J., 22(2), 188-208.

[26] Pyzdek, T. 2003. The Six Sigma handbook. McGraw-Hill

[27] Yang, K. and El-Haik, B.S. 2009. Design for six sigma. McGraw-Hill

[28] Sousa, S.D., Aspinwall, E., Sampaio, P.A. and Rodrigues, A.G. 2005. Performance measures and quality tools in Portuguese small and medium enterprises: Survey results. Total Qual. Manag. Bus. Excell., 16( 2), 277-307.

[29] Antunes, Gloria, Pires, Antonio and Machado, Virgllio. 2009. Process improvement measures in social area organisations: A study in institutions for elderly: Survey results. TQM J., 21(4), 334-352.

[30] Starzyńska B. and Hamrol, A. 2013. Excellence toolbox: Decision support system for quality tools and techniques selection and application. Total Qual. Manag. Bus. Excell., 24(5), 577-595.

[31] Cherrafi, A., Elfezazi, S., Chiarini, A., Mokhlis, A. and Benhida, K. 2016. The integration of lean manufacturing, Six Sigma and sustainability: A literature review and future research directions for developing a specific model. J. Clean. Prod., 139, 828-846.

[32] Zhang, A., Luo, W., Shi, Y., Chia, S. T. and Sim, Z. H. X. 2016. Lean and Six Sigma in logistics: A pilot survey study in Singapore. Int. J. Oper. Prod. Manag., 36(11), 1-21.

[33] Rogala, P. 2016. Identification of barriers to improving quality management systems. TQM J., 28(1), 7988.

[34] Douglas, A., Douglas, J. and Ochieng, J. 2015. Lean Six Sigma implementation in East Africa: Findings from a pilot study. TQM J., 27(6), 772-780.

[35] Aichouni, M., Messaoudene, N.A. Al-Ghonamy, A. and Touahmia, M. 2014. An empirical study of quality management systems in the Saudi construction industry. International Journal of Construction Management, June, 37-41.

[36] Kerfai, N., Bejar Ghadhab, B., and Malouche, D. 2016. Performance measurement and quality costing in Tunisian manufacturing companies. TQM J., 28(4), 588-596.

[37] Santana, D. and Marzagão, L. 2007. Critical success factors for Six Sigma projects. JPMA, 34(8), 20042013.

[38] Zeng, J., Anh Phan, C. and Matsui, Y. 2015. The impact of hard and soft quality management on quality and innovation performance: An empirical study. Int. J. Prod. Econ., 162(August), 216-226.

[39] Kim, D.-Y.,Kumar, V. and Kumar, U. 2012. Relationship between quality management practices and innovation. J. Oper. Manag., 30(4), 295-315.

[40] Bozdogan, K. 2010. Towards an integration of the Lean enterprise system, total quality management, Six Sigma and related enterprise process improvement methods. Encyclopedia of Aerospace Engineering, 6(August), 1-23. 